Sains Malaysiana 49(8)(2020): 1829-1851

http://dx.doi.org/10.17576/jsm-2020-4908-07

\title{
Medicinal Uses, Phytochemistry, and Pharmacological Properties of Piper aduncum L.
}

(Kegunaan Perubatan, Fitokimia dan Sifat Farmakologi Piper aduncum L.)

\author{
Muhammad Taher, Mohamad Shahreen Amri, Deny Susanti*, Muhammad Badri Abdul Kudos, Nur \\ FASYA AJDA MD NOR \& YANDI SYUKRI
}

\begin{abstract}
Piper aduncum L., commonly known as 'spiked pepper', has various uses in traditional medicine that include treating wounds, skin boils, infections, and diarrhoea. Its properties as an anti-parasitic, antimicrobial, insecticidal, antitumor, and anticancer agent indicates that it could have further therapeutic potential in treating infections and cancers. The aim of this review was to provide a comprehensive summary of the traditional uses, phytochemistry and pharmacological properties of P. aduncum. Data were collected from electronic databases from 1978 to 2019. The plant is traditionally used for treating diarrhoea in Peru and for its wound-healing properties in Brazil and Papua New Guinea. Phenolics, monoterpenes, sesquiterpenes, and chromene have been found in the P. aduncum plant, and these bioactive compounds contribute to its anti-parasitic, antimicrobial, insecticidal, antitumor, and anticancer properties. Several pharmacological activities of $\mathrm{P}$. aduncum have been reported, most notably in the treatment of infectious diseases and cancer. However, information regarding its safety and efficacy in humans is lacking. Further study is needed to examine the benefits of $\mathrm{P}$. aduncum and its potential applications in a clinical setting.
\end{abstract}

Keywords: Pharmacological properties; phytochemistry; Piper aduncum; traditional uses

ABSTRAK

Piper aduncum L., yang dikenali sebagai lada berduri, mempunyai pelbagai kegunaan dalam ubat tradisi termasuk merawat luka, bisul kulit, jangkitan dan cirit-birit. Sifatnya sebagai agen anti-parasit, antimikrob, insektisid, antitumor dan antikanser menunjukkan bahawa ia mempunyai potensi terapeutik dalam merawat jangkitan dan kanser. Tujuan kajian ini adalah untuk memberikan ringkasan komprehensif mengenai kegunaan tradisi, fitokimia dan sifat farmakologi P. aduncum. Data telah dikumpulkan dari pangkalan data elektronik dari tahun 1978 hingga 2019. Tumbuhan ini secara tradisinya digunakan untuk merawat cirit-birit di Peru serta menyembuhkan luka di Brazil dan Papua New Guinea. Fenol, monoterpena, sesquiterpena serta kromena telah dijumpai dalam tumbuhan P. aduncum, dan sebatian bioaktif ini menyumbang kepada sifatnya sebagai anti-parasit, antimikrob, insektisid, antitumor dan antikanser. Beberapa aktiviti farmakologi P. aduncum telah dilaporkan, terutamanya dalam rawatan penyakit berjangkit dan kanser. Walau bagaimanapun, maklumat mengenai keselamatan dan keberkesanannya pada manusia adalah kurang. Kajian lanjut diperlukan untuk mengkaji manfaat $\mathrm{P}$. aduncum dan potensi pengaplikasiannya dalam persekitaran klinikal.

Kata kunci: Fitokimia; kegunaan tradisi; Piper aduncum; sifat farmakologi

\section{INTRODUCTION}

Many drugs that are available in the market nowadays have been discovered from natural products including plants. It has been known that plants have their own importance in human history with their interesting phytochemical and pharmacological properties (Flores et al. 2009).

The Piperaceae family comprises around 3600 species. Within this family, the large genus Piper comprises approximately 2000 plant species, including numerous bushes and herbs that can be found in hushed and humid areas, such as jungles and tropical rainforests (Bernuci et al. 2016; Gutiérrez et al. 2016). Piper aduncum is a species in the Piper genus within the Piperaceae family (Ahmad \& Rahmani 1993). It is known as pimenta-demacaco in the Amazon of Brazil and aperta-ruao in the Atlantic Forest of Brazil (de Almeida et al. 2009). It is believed that extracts from $P$. aduncum, which have been shown to have various pharmacological effects, including anti-parasitic, antimicrobial, insecticidal, antitumor, and anticancer properties, can cure many diseases and cancers (Lucena et al. 2017; Mee et al. 2009; Monzote et al. 2017; Ndjonka et al. 2013). 
Although many studies have examined the pharmacological properties of $P$. aduncum, a systematic literature review of this potential therapeutic agent has not yet been conducted. This review reports on the traditional uses, phytochemistry, and pharmacological activities of $P$. aduncum in order to provide an overview of the research and a reference for the comprehensive therapeutic uses of this plant.

\section{METHODS}

Data on the background, traditional uses, phytochemistry, and pharmacological properties of $P$. aduncum were collected from published scientific journals from years 1978 to 2019, using the keywords 'Piper aduncum' and 'Piper species'. Articles, websites, books, and electronic data were collected from academic search engines such as ScienceDirect, Scopus, PubMed, Google Scholar and ResearchGate. The species name of $P$. aduncum L. was validated by the database 'The Plant List' from www. theplantlist.org.

\section{CHARACTERISTICS}

$P$. aduncum, commonly known as 'spiked pepper', is considered the most invasive species of the genus Piper. $P$. aduncum grows as a small tree or shrub and can reach 6 to $8 \mathrm{~m}$ in height, with alternate leaves with short petioles and small fruits arranged in spikes (Ahmad \& Rahmani 1993). The fruits of $P$. aduncum appear as berries that contain small, black seeds. The leaves are 10 to $18 \mathrm{~cm}$ long and have a narrow oval shape that tapers to a point and display a fine network of veins and smooth hairs on the underside (dos Santos et al. 2015). All parts of the $P$. aduncum plant have a peppery smell. The branches of the plant are commonly used as firewood and split easily when continuously exposed to moisture (Rali et al. 2007).

\section{DISTRIBUTION}

$P$. aduncum was mostly originally found in Central and South America, where it grows throughout a large part of the Amazon and Atlantic forests. It was introduced to Asia during the 19th century and is now commonly found throughout New Guinea, Indonesia, Malaysia and the Solomon and Christmas islands (de Almeida et al. 2009; Hartemink 2010; Orjala et al. 1994). It was introduced to the Botanical Gardens of Bogor, Indonesia, possibly as an ornamental (Hartemink 2010).

Due to the large amount of pollen it produces, it is easily spread by the wind. It is also carried efficiently in the faeces of mammals and birds. It grows in areas of evergreen vegetation and water courses in seasonally deciduous forests (Hartemink 2010). As such, P. aduncum can be found in increasingly large geographical areas today.

\section{PHYTOCHEMISTRY OF P. aduncum}

Previous studies have identified several bioactive constituents in $P$. aduncum, including flavonoids, monoterpenes and sesquiterpenes, chalcones, chromenes, phenylpropanoid, and benzoic acid derivatives (Lago et al. 2004; Moreira et al. 1998; Orjala et al. 1994; Rali et al. 2007). It has also been found to contain 23 essential oil components (Oliveira et al. 2013).

\section{PHYTOCHEMICAL CONSTITUENTS IN THE LEAVES OF

$$
\text { P. aduncum }
$$

$P$. aduncum contains a wide range of phytochemical compounds, such as flavonoids, monoterpenes, sesquiterpenes, chalcones and benzoic acid derivatives, as summarised in Table 1.

TABLE 1. Compounds from the leaves of Piper aduncum

\begin{tabular}{llc}
\hline \multicolumn{1}{c}{ Class of compound } & \multicolumn{1}{c}{ Compound } & References \\
\hline Flavonoids & Gallic acid (1) & (Escudero et al. 2008) \\
& Catechin (2) & \\
& Chlorogenic acid (3) & \\
& Epicatechin (4) & \\
& Quercetin-3-rutinoside (5) \\
& Quercetin-3-rhamnoside (6) \\
& Phloridzin (7) \\
& Quercetin (8) \\
& Phloretin (9)
\end{tabular}




\begin{tabular}{|c|c|c|}
\hline Mono- and sesquiterpenes & $\begin{array}{l}\alpha \text {-pinene (10) } \\
\beta \text {-pinene (11) } \\
\text { Limonene (12) } \\
\text { (e)-ocimene (13) } \\
\text { (z)-ocimene (14) } \\
\text { Linalool (15) } \\
\alpha \text {-copaene (16) } \\
\beta \text {-elemene (17) } \\
\alpha \text {-gurjunene (18) } \\
\beta \text {-caryophyllene (19) } \\
\text { Allo-aromadendrene (20) } \\
\alpha \text {-humulene (21) } \\
\text { Undecanone (22) } \\
\text { Germacrene d (23) } \\
\text { bicyclogermacrene (24) } \\
\alpha \text {-muurolene (25) } \\
\gamma \text {-cadinene (26) } \\
\delta \text {-cadinene (27) } \\
\text { Germacrene b (28) } \\
\text { Nerolidol (29) } \\
\text { Spathulenol (30) } \\
\text { Globulol (31) } \\
\text { Safrole (32) } \\
\beta \text {-gurjunene (33) } \\
\beta \text {-sesquiphellandrene (34) } \\
\text { Rosifoliol (35) } \\
\text { Humulene epoxide ii (36) } \\
\text { Epi-cubenol (37) } \\
\alpha \text {-muurolol (38) } \\
\alpha \text {-cadinol (39) } \\
\text { Shyobunol (40) } \\
\text { Piperitone (41) }\end{array}$ & $\begin{array}{l}\text { (Bernuci et al. 2016; Navickiene et al. 2006; Oliveira et al. } \\
\text { 2013; Rali et al. 2007) }\end{array}$ \\
\hline Chalcones & $\begin{array}{l}\text { Adunctins A (42) } \\
\text { Adunctins B (43) } \\
\text { Adunctins C (44) } \\
\text { Adunctins D (45) } \\
\text { Adunctins E (46) } \\
\text { Cardamonin (47) } \\
\text { Piperaduncin A (48) } \\
\text { Piperaduncin B (49) } \\
\text { Piperaduncin C (50) } \\
\text { Asebogenin (51) } \\
\text { 2',6'-dihydroxy-4'- } \\
\text { methoxydihydrochalcone (52) } \\
\text { Uvangoletin (53) }\end{array}$ & (Orjala et al. 1994) \\
\hline Phenylpropanoid & Dillapiole (54) & (Rali et al. 2007) \\
\hline Benzoic acid derivatives & $\begin{array}{l}\text { 3-(3,7-dimethyl-2,6-octadienyl)- } \\
\text { 4-methoxy-benzoic acid (55) } \\
\text { 4-hydroxy-3-(3,7-dimethyl-2,6- } \\
\text { octadienyl) benzoic acid (56) } \\
\text { 4-hydroxy-3-(3-methyl-1-oxo-2- } \\
\text { butenyl-5(3-methyl-2-butenyl) } \\
\text { benzoic acid (57) } \\
\text { Methyl 4-hydroxy-3-(2'- } \\
\text { hydroperoxy-3'-methyl-3'- } \\
\text { butenyl)benzoate (58) } \\
\text { Methyl 4-hydroxy-3-(2'- } \\
\text { hydroxy-3'-methyl-3'-butenyl) } \\
\text { benzoate (59) } \\
\text { Aduncumene (60) }\end{array}$ & (Flores et al. 2009; Lago et al. 2009) \\
\hline
\end{tabular}


FLAVONOIDS

Ethanolic extracts of $P$. aduncum leaves have shown the presence of large amounts of flavonoids (ArroyoAcevedo et al. 2015). Flavonoids, which are polyphenolic compounds, have antioxidant properties and are able to scavenge free radicals and therefore have utility in<smiles>O=C(O)c1cc(O)c(O)c(O)c1</smiles>

Gallic acid (1)<smiles>O=C(/C=C/c1ccc(O)c(O)c1)O[C@@H]1C[C@@](O)(C(=O)O)C[C@H](O)[C@H]1O</smiles>

Chlorogenic acid (3)<smiles>C[C@H]1O[C@H](OCC2O[C@H](Oc3c(-c4ccc(O)c(O)c4)oc4cc(O)cc(O)c4c3=O)[C@H](O)[C@H](O)[C@@H]2O)[C@H](O)[C@@H](O)[C@@H]1O</smiles>

Quercetin-3-rutinoside (5) cancer treatment. As reported by Escudero et al. (2008), ethanolic extracts of $P$. aduncum leaves originating from the Peruvian rainforest showed flavonoid compounds as the predominant compounds in the plant. The flavonoid constituents identified in $P$. aduncum are shown in Figure 1.<smiles>Oc1cc(O)c2c(c1)O[C@H](c1ccc(O)c(O)c1)C(O)C2</smiles>

Catechin (2)<smiles>Oc1cc(O)c2c(c1)O[C@H](c1ccc(O)c(O)c1)C(O)C2</smiles>

Epicatechin (4)<smiles>C[C@H]1OC(Oc2c(-c3ccc(O)c(O)c3)oc3cc(O)cc(O)c3c2=O)[C@H](O)[C@H](O)[C@@H]1O</smiles>

Quercetin-3-rhamnoside (6) 
<smiles>O=C(CCc1ccc(O)cc1)c1c(O)cc(O)cc1O[C@@H]1O[C@H](CO)[C@@H](O)[C@H](O)[C@H]1O</smiles><smiles>O=c1c(O)c(-c2ccc(O)c(O)c2)oc2cc(O)cc(O)c12</smiles>

Quercetin (8)

\section{Phloridzin (7)}<smiles>O=C(CCc1ccc(O)cc1)c1c(O)cc(O)cc1O</smiles>

Phloretin (9)

FIGURE 1. Flavonoid compounds identified in Piper aduncum leaves

\section{MONOTERPENES AND SESQUITERPENES}

The presence of monoterpenes and sesquiterpenes (Figure 2) in the phytochemical analysis of $P$. aduncum leaves has been extensively reported (Escudero et al. 2008). The results obtained in separate studies all correlated with one another in terms of their finding that $P$. aduncum leaves contain larger amounts of sesquiterpene compounds $(90.4 \%)$ than monoterpenes (7.0\%). 1,8-Cineole has been found to be the major component of $P$. aduncum essential oil (Oliveira et al. 2013). The essential oil of $P$. aduncum leaves originating from Brazil has been shown to contain $\alpha$-pinene (10), $\beta$-pinene (11), limonene (12), (E)-ocimene (13), (Z)-ocimene (14) and linalool (15) (Navickiene et al. 2006). The sesquiterpenes identified by GC-MS analyses are $\alpha$-copaene (16), $\beta$-elemene (17), $\alpha$-gurjunene (18), $\beta$-caryophyllene (19), allo-aromadendrene (20), $\alpha$-humulene (21), undecanone (22), germacrene D (23), bicyclogermacrene (24), $\alpha$-muurolene (25), $\gamma$-cadinene
(26), $\delta$-cadinene (27), germacrene B (28), nerolidol (29), spathulenol (30) and globulol (31).

Bernuci et al. (2016) showed that the essential oil of fresh P. aduncum leaves from Santa Catrina, Brazil, is rich in sesquiterpenes. The monoterpene compounds identified were (E)-ocimene (13), (Z)-ocimene (14), linalool (15) and safrole (32). The sesquiterpenes identified were $\beta$-caryophyllene (19), $\beta$-gurjunene (33), $\alpha$-humulene (21), allo-aromadendrene (20), bicyclogermacrene (24), $\gamma$-cadinene (26), $\beta$-sesquiphellandrene (34), spathulenol (30), rosifoliol (35), humulene epoxide II (36), epi-cubenol (37), $\alpha$-muurolol (38), $\alpha$-cadinol (39) and shyobunol (40). Analysis conducted by Rali et al. (2007) showed that the dominant compounds in $P$. aduncum leaf essential oil from Papua New Guinea were $\beta$-caryophyllene (19), piperitione (41) and $\alpha$-humulene (21). Figure 2 shows the monoterpenes and sesquiterpenes identified in the analysis of $P$. aduncum leaves. 


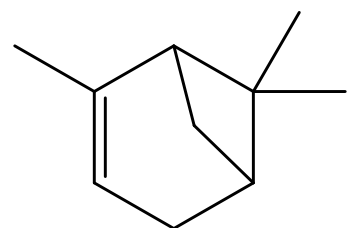

$\alpha$-pinene (10)

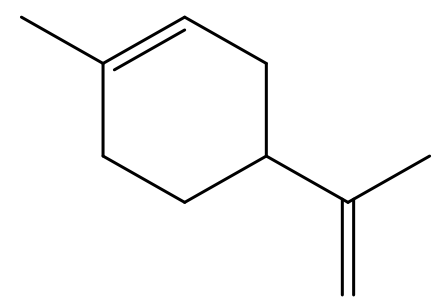

Limonene (12)

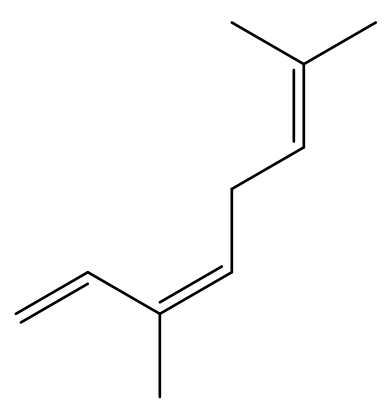

(Z)-ocimene (14)

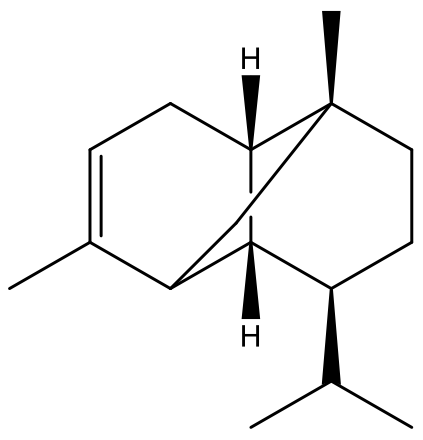

$\alpha$-copaene (16)

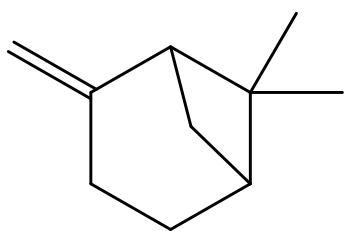

$\beta$-pinene (11)

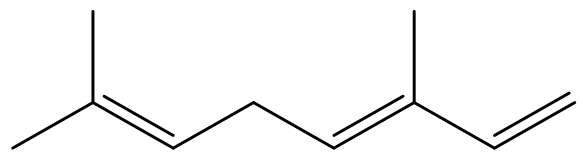

(E)-ocimene (13)
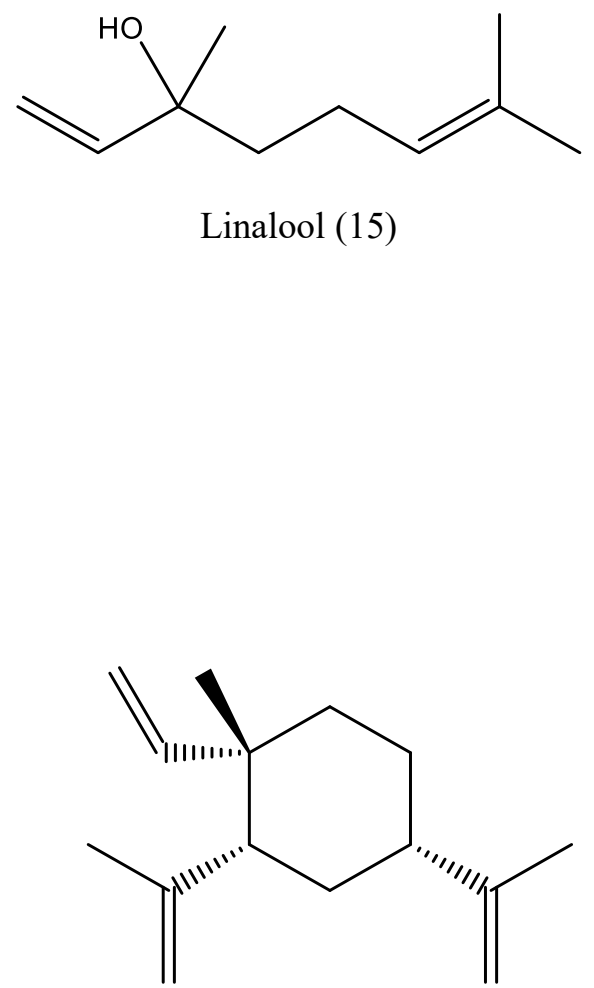

$\beta$-elemene (17) 


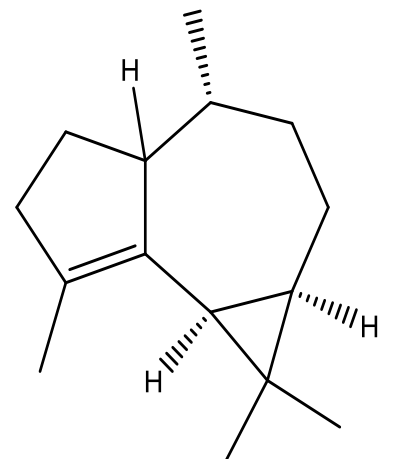

$\alpha$-gurjunene (18)

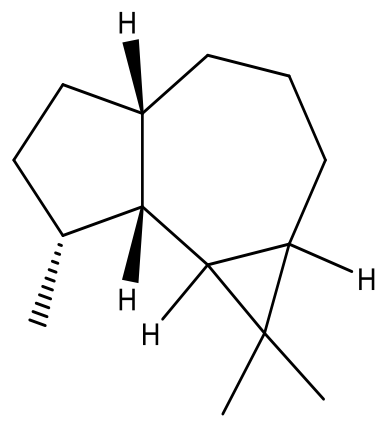

Allo- Aromadendrene (20)<smiles>CCCCCCCCCC(C)=O</smiles>

Undecanone (22)

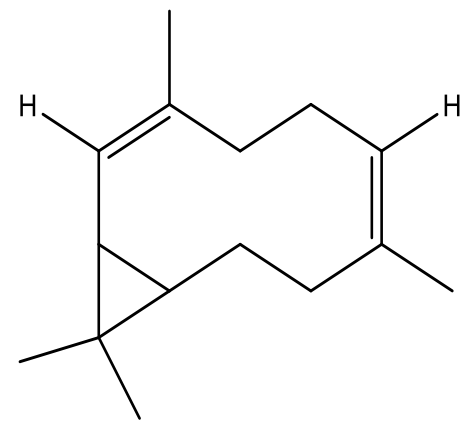

Bicyclogermacrene (24)

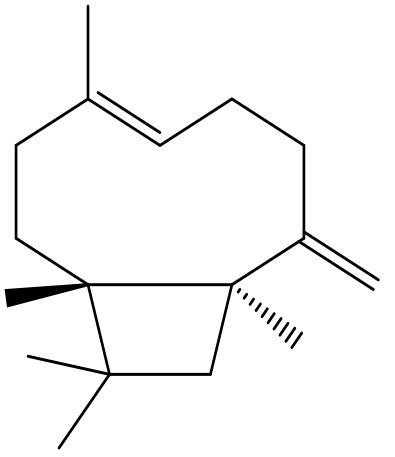

$\beta$-caryophyllene (19)

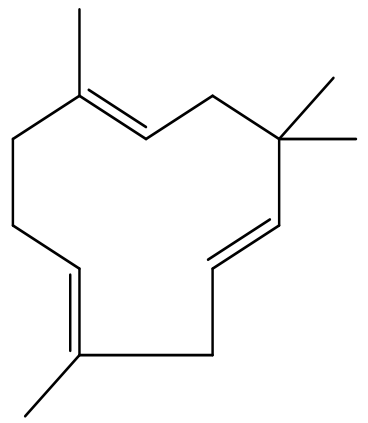

$\alpha$-humulene (21)

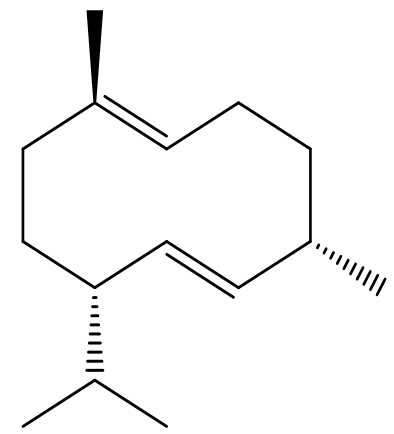

Germacrene D (23)

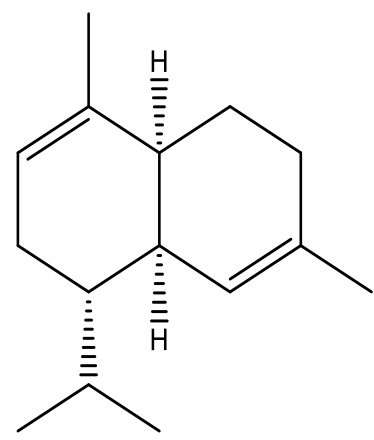

$\alpha$-muurolene (25) 


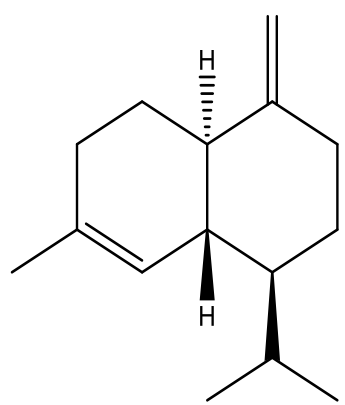

$\gamma$-cadinene (26)

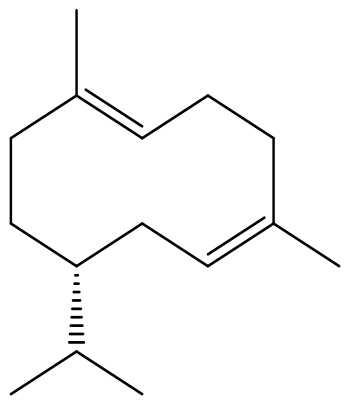

germacrene B (28)

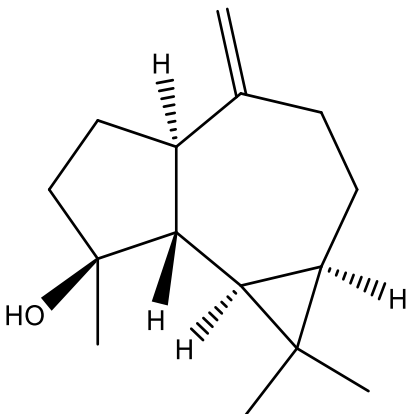

Spathulenol (30)<smiles>C=CCc1ccc2c(c1)OCO2</smiles>

Safrole (32)

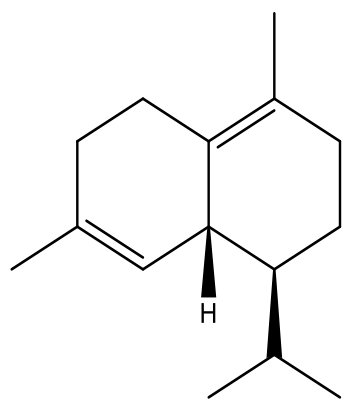

$\delta$-cadinene (27)

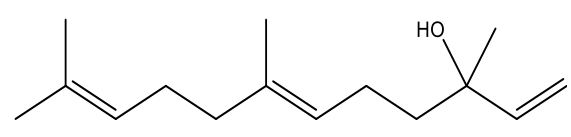

Nerolidol (29)

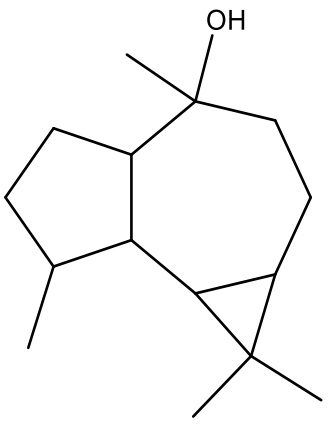

Globulol (31)

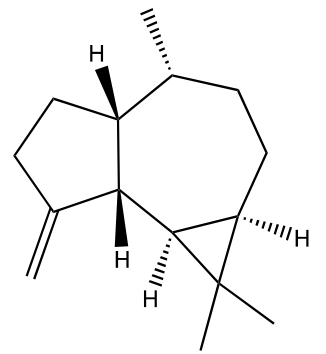

B-gurjunene (33) 

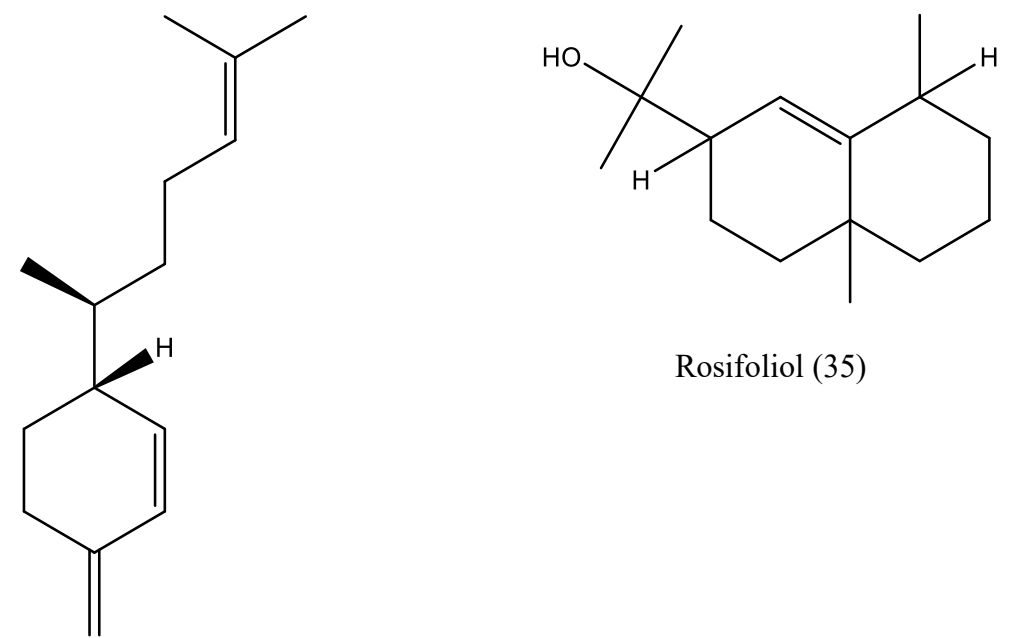

Rosifoliol (35)

$\beta$-sesquiphellandrene (34)

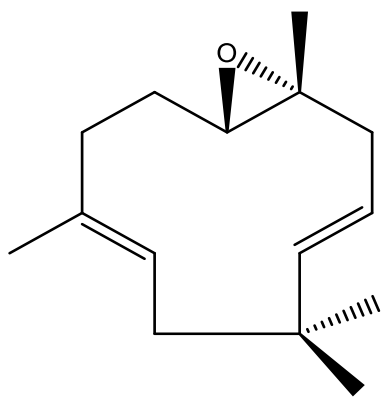

Humulene epoxide II (36)

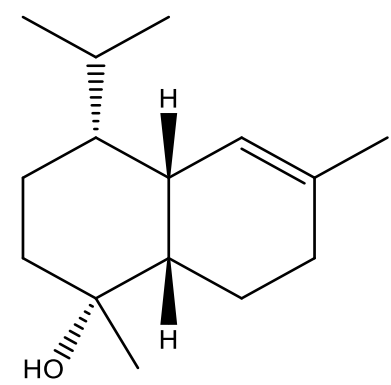

$\alpha$-muurolol (38)

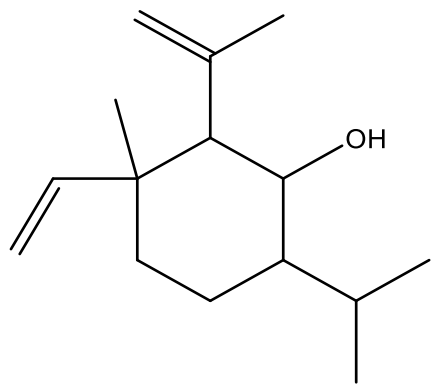

Shyobunol (40)

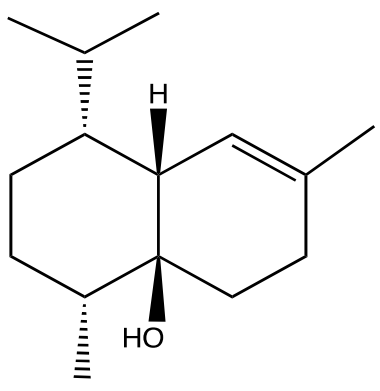

Epi-cubenol (37)<smiles>CC(C)[C@H]1CC[C@@H](C)[C@]2(O)CC[C@@H](C)C[C@@H]12</smiles>

$\alpha$-cadinol (39)

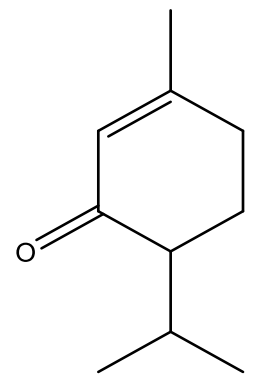

Piperitone (41)

FIGURE 2. Chemical structures of mono- and sesquiterpenes found in Piper aduncum leaves 


\section{CHALCONES}

Orjala et al. (1994) isolated chalcones and previously unidentified monoterpenes-substituted dihydochalcones from the leaves of $P$. aduncum, which were adunctins A-E (42-46). Piperaduncin A-C (48-50), asebogenin (51) and 2',6'-dihydroxy-4'-methoxydihydrochalcone (52) were

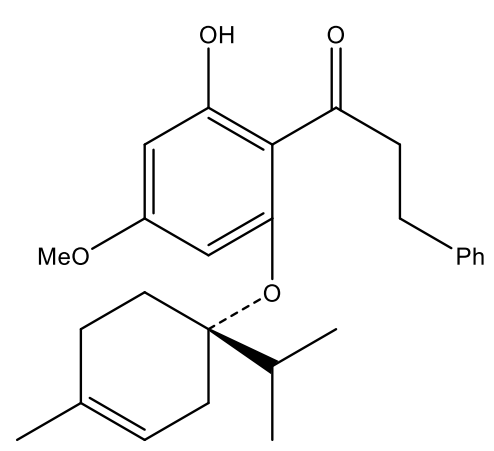

Adunctins A (42)

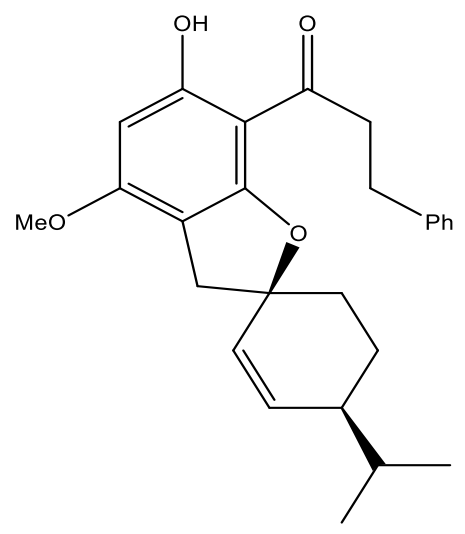

Adunctins C (44)

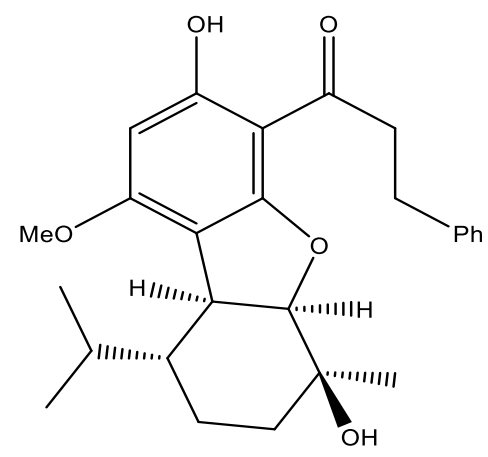

Adunctins E (46) also isolated from the leaves of $P$. aduncum (Orjala et al. 1994). Cardamonin (47) and uvangoletin (53) (Figure 3) were isolated from $P$. aduncum leaves originating from Brazil by solvent extraction with $\mathrm{CH}_{2} \mathrm{Cl}_{2}$ (de Castro et al. 2015).

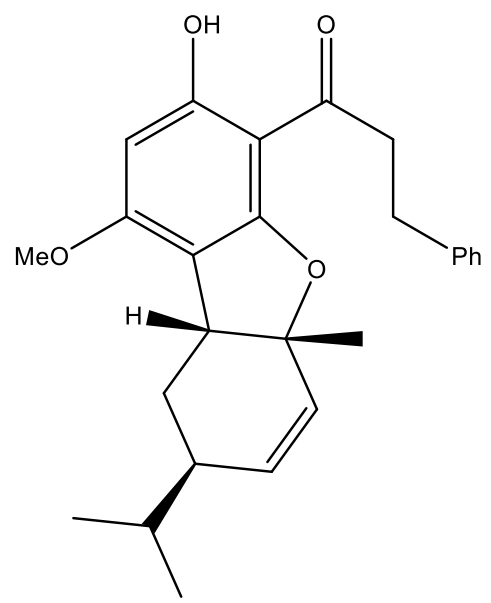

Adunctins B (43)<smiles>COc1cc(O)c(C(=O)CCc2ccccc2)c2c1C[C@]1(C=C[C@@H](C(C)C)CC1)O2</smiles>

Adunctins D (45)<smiles>COc1cc(O)cc(O)c1C(=O)/C=C/c1ccccc1</smiles>

Cardamonin (47) 


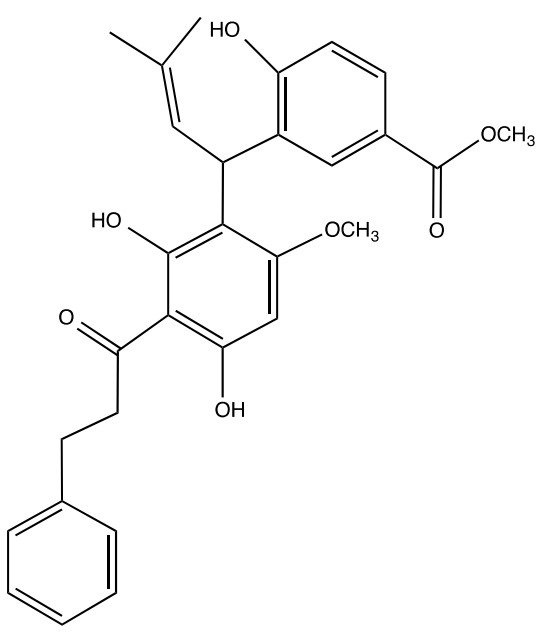

Piperaduncin A (48)

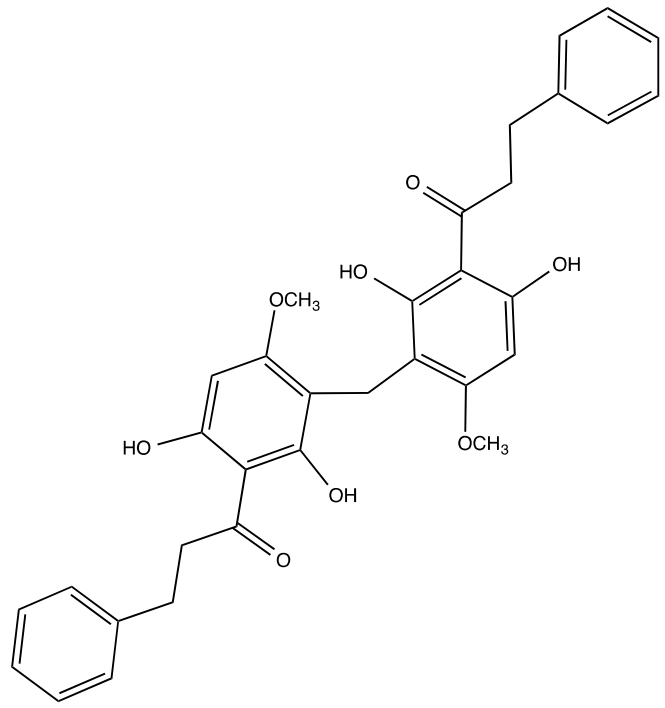

Piperaduncin C (50)

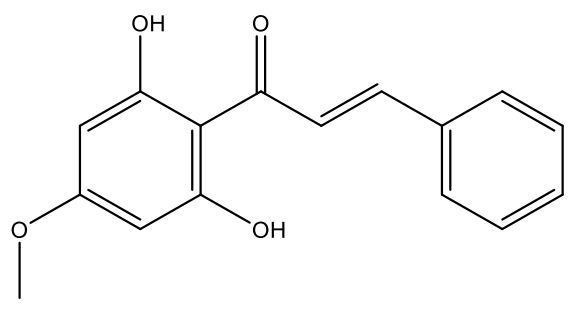

2',6'-dihydroxy-4'-methoxydihydrochalcone<smiles>COc1cc(O)cc(O)c1C(=O)CCc1ccccc1</smiles>

Uvangoletin (53)

(52)

FIGURE 3. Chemical structures of chalcones isolated from Piper aduncum leaves 


\section{PHENYLPROPANOID}

The essential oil of $P$. aduncum is rich in dillapiole (54) (Figure 4), which is a derivative of phenylpropene. Rali et al. (2007) identified dillapiole as the main volatile constituent of the essential oil from the leaves of $P$. aduncum from the Brazilian Amazon rainforest, Costa Rica, Cuba, Malaysia, and Fiji. Ahmad and Rahmani (1993) also identified dillapiole as the main constituent (43.3\%) in P. aduncum leaves from Puchong, Malaysia.
However, essential oil from the Brazilian Atlantic forest was found to contain nerolidol and linalool as the two main volatile components (de Almeida et al. 2009). The variety of compounds present in $P$. aduncum essential oils indicate that different chemical variations have led to the formation of two chemo types. Dillapiole is produced via the shikimate pathway, and terpenes and linalool are produced via the mevalonate or acetate pathway.<smiles>C=CCc1cc2c(c(OC)c1OC)OCO2</smiles>

FIGURE 4. Chemical structure of dillapiole (54)

\section{BENZOIC ACID DERIVATIVES}

Flores et al. (2009) conducted a phytochemical analysis of the leaves of $P$. aduncum and isolated the prenylated hydroxybenzoic acid derivatives namely 3-(3,7-dimethyl2,6-octadienyl)-4-methoxy-benzoic acid (55), 4-hydroxy3-(3,7-dimethyl-2,6-octadienyl) benzoic acid (56) and 4-hydroxy-3-(3-methyl-1-oxo-2-butenyl-5(3-methyl-2- butenyl) benzoic acid (57) (Figure 5). Additional two prenylated methyl benzoates have also been isolated from $P$. aduncum leaves which are methyl 4-hydroxy-3(2'-hydroperoxy-3'-methyl-3'-butenyl)benzoate (58) and methyl 4-hydroxy-3-(2'-hydroxy-3'-methyl-3'-butenyl) benzoate (59) (Lago et al. 2009). Aduncumene (60) was isolated after successive extractions using different solvents and column chromatography.<smiles>CC(C)=CCc1cc(C(=O)O)cc(C(=O)C=C(C)C)c1O</smiles>

4-hydroxy-3-(3-methyl-1-oxo-2-butenyl5(3-methyl-2-butenyl) benzoic acid (57)<smiles>C=C(C)C(O)Cc1cc(C(C)=O)ccc1O</smiles>

Methyl 4-hydroxy-3-(2'-hydroperoxy-3'methyl-3'-butenyl)benzoate (58)

Methyl 4-hydroxy-3-(2'-hydroxy-3'methyl-3'-butenyl)benzoate (59) 


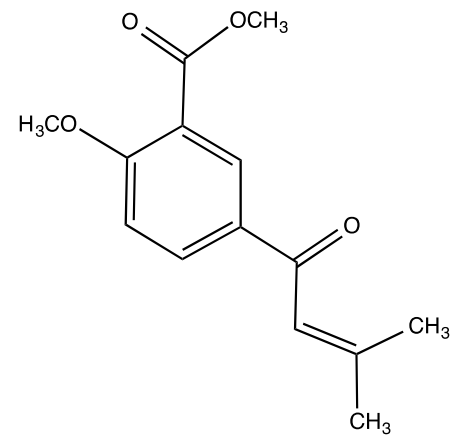

Aduncumene (60)

FIGURE 5. Isolated benzoic acid derivatives from Piper aduncum leaves

PHYTOCHEMICAL CONSTITUENTS IN THE STEMS OF

$$
\text { P. aduncum }
$$

Several monoterpenes, including $\alpha$-pinene (10), $\beta$-pinene (11), myrcene (61), $\alpha$-terpinene (62), $p$-cimene (63), limonene (12), (E)-ocimene (13), (Z)-ocimene (14), $\gamma$-terpinene (64) and linalool (15), have been identified in the stems of $P$. aduncum, in addition to the sesquiterpenes $\beta$-caryophyllene, $\alpha$-humulene, germacrene $\mathrm{D}$, and nerolidol (Navickiene et al. 2006). A separate study identified monoterpenes and sesquiterpenes such as $\beta$-pinene (11), myrcene (61), $\alpha$-terpinene (62), $\alpha$-phellendrene (65), m-cimene (66), 1,8-cineole (67), bornyl acetate (68), neryl acetate (69), geranyl acetate (70), and copaene (71) (Moreira et al. 1998). The chromenes eupatoriochromene (72) and methyl 2,2-dimethyl-8-(3-methyl-2-butenyl)-2Hchromene-6-carboxylate (73) have also been identified. The chemical structures of bioactive compounds isolated from the stems of P. aduncum are shown in Figure 6.<smiles>C=CC(=C)CCC=C(C)C</smiles>

Myrcene (61)<smiles>Cc1ccc(C(C)C)cc1</smiles>

p-cimene (63)<smiles>CC1=CC=C(C(C)C)CC1</smiles>

$\alpha$-terpinene (62)<smiles>CC1=CCC(C(C)C)=CC1</smiles>

$\gamma$-terpinene (64) 
<smiles>CC1=CCC(C(C)C)C=C1</smiles>

$\alpha$-Phellendrene (65)

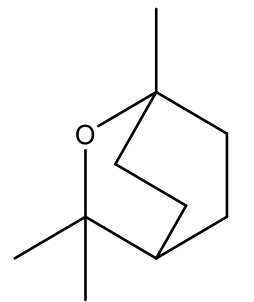

1,8-Cineole (67)

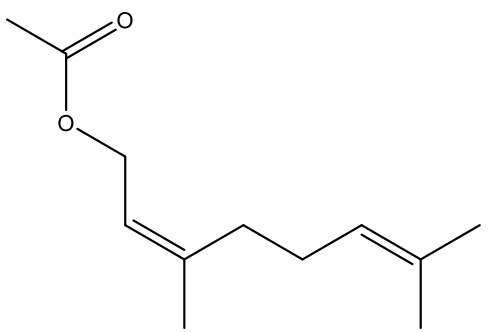

Neryl acetate (69)

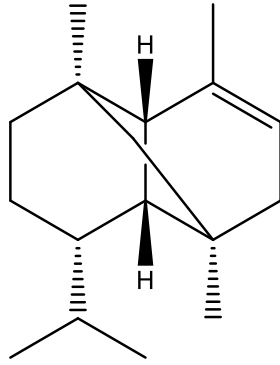

Copaene (71)

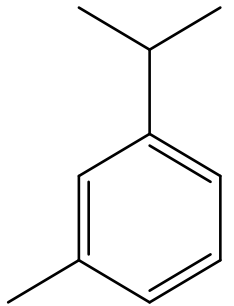

m-cimene $(66)$

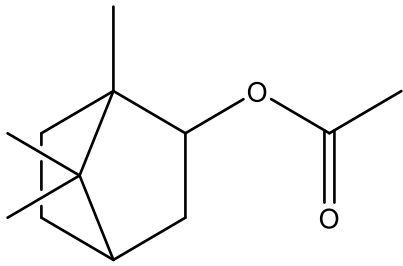

Bornyl acetate (68)<smiles>CC(=O)OC/C=C(\C)CCC=C(C)C</smiles>

Geranyl acetate (70)

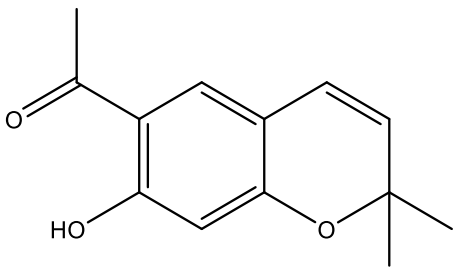

Eupatoriochromene (72)<smiles>COC(=O)c1cc2c(c(CC=C(C)C)c1)OC(C)(C)C=C2</smiles>

Methyl 2,2-dimethyl-8-(3-methyl-2-butenyl)-2-H-chromene-6-carboxylate (73) 
PHYTOCHEMICAL CONSTITUENTS IN THE FRUITS OF

P. aduncum

The fruits of $P$. aduncum have been analysed using a chemical extraction process and have been shown to contain both monoterpenes and sesquiterpenes (Navickiene et al. 2006). The specific compounds identified in the fruits are $\alpha$-pinene (10), $\beta$-pinene (11), myrcene, $\alpha$-terpinene, limonene (12), 1,8-cineole, (E)-ocimene (13), (Z)-ocimene (14), $\gamma$-terpinene (64), linalool (15), $\beta$-caryophyllene (19), $\alpha$-humulene (21), germacrene D (25) and nerolidol (29). Other dihydrochalcone compounds, including $2^{\prime}$-hydroxy4',6'-dimethoxydihydrochalcone (74), 2',6'-dihydroxy4'-methoxydihydrochalcone (52), 2'4-dihydroxy-4',6',3trimethoxydihydrochalcone (75) and 2',4-dihydroxy-4'6'-dimethoxydihydrochalcone (76), have been isolated from hexane extracts of $P$. aduncum fruits (Moreira et al. 1998). The chemical structures of these dihydrochalcones are shown in Figure 7.<smiles>COc1cc(O)c(C(=O)/C=C/c2ccccc2)c(OC)c1</smiles>

2'-hydroxy-4',6'-dimethoxydihydrochalcone (74)<smiles>COc1cc(O)c(C(=O)/C=C/c2ccc(O)c(OC)c2)c(OC)c1</smiles>

2’4-dihydroxy-4',6',3-trimethoxydihydrochalcone (75)<smiles>COc1cc(O)c(C(=O)/C=C/c2ccc(O)cc2)c(OC)c1</smiles>

2'.4-dihydroxy-4'-6'-dimethoxydihydrochalcone (76)

FIGURE 7. Chemical structures of dihydrochalcones found in Piper aduncum fruits 
Different phytochemical constituents have been found in varying quantities in different parts of the $P$. aduncum plant, and different parts of the plant have been shown to contain different types of compounds (Table 2).

TABLE 2. Summary of the compounds from the leaves, stems, and fruits of $P$. aduncum

\begin{tabular}{|c|c|c|}
\hline Leaves & Stems & Fruits \\
\hline Gallic acid (1) & $\alpha$-pinene (10) & $\alpha$-pinene (10) \\
\hline Catechin (2) & $\beta$-pinene (11) Limonene (12) & $\beta$-pinene (11) \\
\hline Chlorogenic acid (3) & (E)-ocimene (13) & Myrcene (61) \\
\hline Epicatechin (4) & $(\mathrm{Z})$-ocimene $(14)$ & $\alpha$-terpinene (62) \\
\hline Quercetin-3-rutinoside (5) & Linalool (15) & Limonene (12) \\
\hline Quercetin-3-rhamnoside (6) & $\beta$-caryophyllene (19) & 1,8-cineole $(67)$ \\
\hline Phloridzin (7) & $\alpha$-humulene (21) & (E)-ocimene (13) \\
\hline Quercetin (8) & Germacrene d(23) & $(\mathrm{Z})$-ocimene $(14)$ \\
\hline Phloretin (9) & Nerolidol (29) & $\gamma$-terpinene, linalool (15) \\
\hline$\alpha$-pinene (10) & Myrcene (61) & $\beta$-caryophyllene (19) \\
\hline$\beta$-pinene (11) & $\alpha$-terpinene (62) & $\alpha$-humulene (21) \\
\hline Limonene (12) & $p$-cimene (63) & Germacrene D (25) \\
\hline (e)-ocimene (13) & $\gamma$-terpinene (64) & Nerolidol (29) \\
\hline (z)-ocimene (14) & $\alpha$-phellendrene (65) & 2',6'-dihydroxy-4'- \\
\hline Linalool (15) & m-cimene (66) & methoxydihydrochalcone (52) \\
\hline$\alpha$-copaene (16) & bornyl acetate (68) & 2'-hydroxy-4',6'- \\
\hline$\beta$-elemene (17) & neryl acetate (69) & dimethoxydihydrochalcone (74) \\
\hline$\alpha$-gurjunene (18) & geranyl acetate $(70)$ & 2’4-dihydroxy-4',6',3- \\
\hline$\beta$-caryophyllene (19) & copaene $(71)$ & trimethoxydihydrochalcone (75) \\
\hline Allo-aromadendrene (20) & eupatoriochromene (72) & 2'.4-dihydroxy-4'-6'- \\
\hline$\alpha$-humulene (21) & methyl 2,2-dimethyl-8-(3-methyl-2-butenyl)- & dimethoxydihydrochalcone (76) \\
\hline Undecanone (22) & 2H-chromene-6-carboxylate (73) & \\
\hline \multicolumn{3}{|l|}{ Germacrene d (23) } \\
\hline \multicolumn{3}{|l|}{ Bicyclogermacrene (24) } \\
\hline \multicolumn{3}{|l|}{$\alpha$-muurolene (25) } \\
\hline \multicolumn{3}{|l|}{$\gamma$-cadinene $(26)$} \\
\hline \multicolumn{3}{|l|}{$\delta$-cadinene $(27)$} \\
\hline \multicolumn{3}{|l|}{ Germacrene b (28) } \\
\hline \multicolumn{3}{|l|}{ Nerolidol (29) } \\
\hline \multicolumn{3}{|l|}{ Spathulenol (30) } \\
\hline \multicolumn{3}{|l|}{ Globulol (31) } \\
\hline \multicolumn{3}{|l|}{ Safrole (32) } \\
\hline \multicolumn{3}{|l|}{ B-gurjunene (33) } \\
\hline \multicolumn{3}{|l|}{ B-sesquiphellandrene (34) } \\
\hline \multicolumn{3}{|l|}{ Rosifoliol (35) } \\
\hline \multicolumn{3}{|l|}{ Humulene epoxide ii (36) } \\
\hline \multicolumn{3}{|l|}{ Epi-cubenol (37) } \\
\hline \multicolumn{3}{|l|}{ A-muurolol (38) } \\
\hline A-cadinol (39) & & \\
\hline
\end{tabular}


Shyobunol (40)

Piperitone (41)

Adunctins A (42)

Adunctins B (43)

Adunctins C (44)

Adunctins D (45)

Adunctins E (46)

Cardamonin (47)

Piperaduncin A (48)

Piperaduncin B (49)

Piperaduncin C (50)

Asebogenin (51)

2',6'-dihydroxy-4'-

methoxydihydrochalcone (52)

Uvangoletin (53)

Dillapiole (54)

3-(3,7-dimethyl-2,6-octadienyl)-4-

methoxy-benzoic acid (55)

4-hydroxy-3-(3,7-dimethyl-2,6-

octadienyl) benzoic acid (56)

4-hydroxy-3-(3-methyl-1-oxo-2-butenyl-

5(3-methyl-2-butenyl) benzoic acid (57)

Methyl 4-hydroxy-3-(2'-hydroperoxy-3'-

methyl-3'-butenyl)benzoate (58)

Methyl 4-hydroxy-3-(2'-hydroxy-3'-

methyl-3'-butenyl)benzoate (59)

Aduncumene (60)

\section{TRADITIONAL USES OF P. aduncum TREATMENT OF DIARRHOEA}

In traditional folk medicine, $P$. aduncum is widely used in Jamaica for treating stomach aches, in Peru for treating diarrhoea and in Colombia as a remedy for dysentery (Luyen et al. 2017; Orjala et al. 1994; Thao et al. 2016). Traditionally, an infusion of $P$. aduncum leaves is used by Peruvian people as an alternative therapy for treating diseases with symptomatic diarrhoea, due to the plant's antimicrobial, astringent, diuretic, stimulant, and stomachic properties (Duarte et al. 2007; Morandim et al. 2005). The essential oil of $P$. aduncum has been shown to ameliorate diarrhoea caused by Escherichia coli. A minimal inhibitory concentration (MIC) of $1000 \mu \mathrm{g} /$ $\mathrm{mL} P$. aduncum essential oil successfully inhibited enterohaemorrhagic $E$. coli, $900 \mu \mathrm{g} / \mathrm{mL}$ enteropathogenic $E$. coli and enteroinvasive $E$. coli (Duarte et al. 2007).

\section{TREATMENT OF WOUNDS}

$P$. aduncum is used in traditional Brazilian and Papua New Guinean folk medicine for treating wounds due to its antiseptic and anti-inflammatory properties (Morandim et al. 2005). The leaves are used in herbal remedies in two ways. The first involves making an infusion of the leaves, which is then used to wash the bleeding area. The second method is to crush the leaves and sprinkle them onto a wound (Dal Picolo et al. 2014; Mee et al. 2009). Recent studies have found that the essential oil of $P$. aduncum has strong antimicrobial activity against many common microorganisms that cause wounds to become infected, such as Staphylococcus epidermis, S. aureus and Pseudomonas aeruginosa. In one study, the MIC value of isolated compounds for P. aeruginosa, Bacillus subtillis, and $S$. aureus was reported to be more than $100 \mu \mathrm{g} / \mathrm{mL}$ (Okunade et al. 1997). In addition, one in vitro study 
demonstrated a highly significant anti-inflammatory effect of a methanolic extract of $P$. aduncum, with an inhibition value of $20 \mu \mathrm{g} / \mathrm{mL}$ (Thao et al. 2016).
PHARMACOLOGICAL PROPERTIES OF P. aduncum

Table 3 provides a summary of the pharmacological properties of $P$. aduncum.

TABLE 3. Summary of pharmacological properties of $P$. aduncum

\begin{tabular}{|c|c|c|c|c|c|c|c|}
\hline $\begin{array}{l}\text { Pharmacological } \\
\text { Properties }\end{array}$ & $\begin{array}{l}\text { Plant } \\
\text { Parts }\end{array}$ & Extracts & Methods & Mechanisms & $\begin{array}{l}\text { Concentration } \\
\text { / dose }\end{array}$ & Constituents & References \\
\hline \multirow[t]{4}{*}{ Anti-fungal } & Leaves & Ethanol & $\begin{array}{c}\text { In vitro on } C \text {. } \\
\text { cladosporiodes } \\
\text { and } C \text {. } \\
\text { sphaerospermum }\end{array}$ & n.a & $\begin{array}{c}\text { MIC: } 0.5-5.0 \\
\mu \mathrm{g}\end{array}$ & $\begin{array}{c}\text { Benzoic acid } \\
\text { derivatives and } \\
\text { chromenes }\end{array}$ & $\begin{array}{l}\text { (Lago et al. } \\
\text { 2004) }\end{array}$ \\
\hline & Fruits & n.a & $\begin{array}{c}\text { Direct } \\
\text { bioautography } \\
\text { on TLC plate } \\
\text { against } C \text {. } \\
\text { cladosporiodes } \\
\text { and } C \text {. } \\
\text { sphaerospermum }\end{array}$ & n.a & MIC: $10 \mu \mathrm{g}$ & $\begin{array}{l}\text { Monoterpenes } \\
\text { (Linalool) }\end{array}$ & $\begin{array}{l}\text { (Navickiene } \\
\text { et al. 2006) }\end{array}$ \\
\hline & $\begin{array}{c}\text { Aerial } \\
\text { part }\end{array}$ & n.a & $\begin{array}{l}\text { In vitro against } \\
\text { Clinipellis } \\
\text { perniciosa } \\
\text { (witches } \\
\text { broom) }\end{array}$ & n.a & $\begin{array}{l}\text { MIC: } 0.6- \\
1.0 \mathrm{ppm}\end{array}$ & Dillapiole & $\begin{array}{l}\text { (de Almeida } \\
\text { et al. 2009) }\end{array}$ \\
\hline & Leaves & Ethanol & $\begin{array}{l}\text { In vitro inhibitory } \\
\text { activity against } \\
\text { Cryptococcus } \\
\text { neoformans and } \\
\text { Candida albicans }\end{array}$ & n.a & $\begin{aligned} & \mathrm{MIC}:>100 \mu \mathrm{g} / \\
& \mathrm{mL}\end{aligned}$ & $\begin{array}{c}\text { Benzoic acid, } \\
\text { chalcones and } \\
\text { chromenes }\end{array}$ & $\begin{array}{l}\text { (Okunade et } \\
\text { al. 1997) }\end{array}$ \\
\hline
\end{tabular}

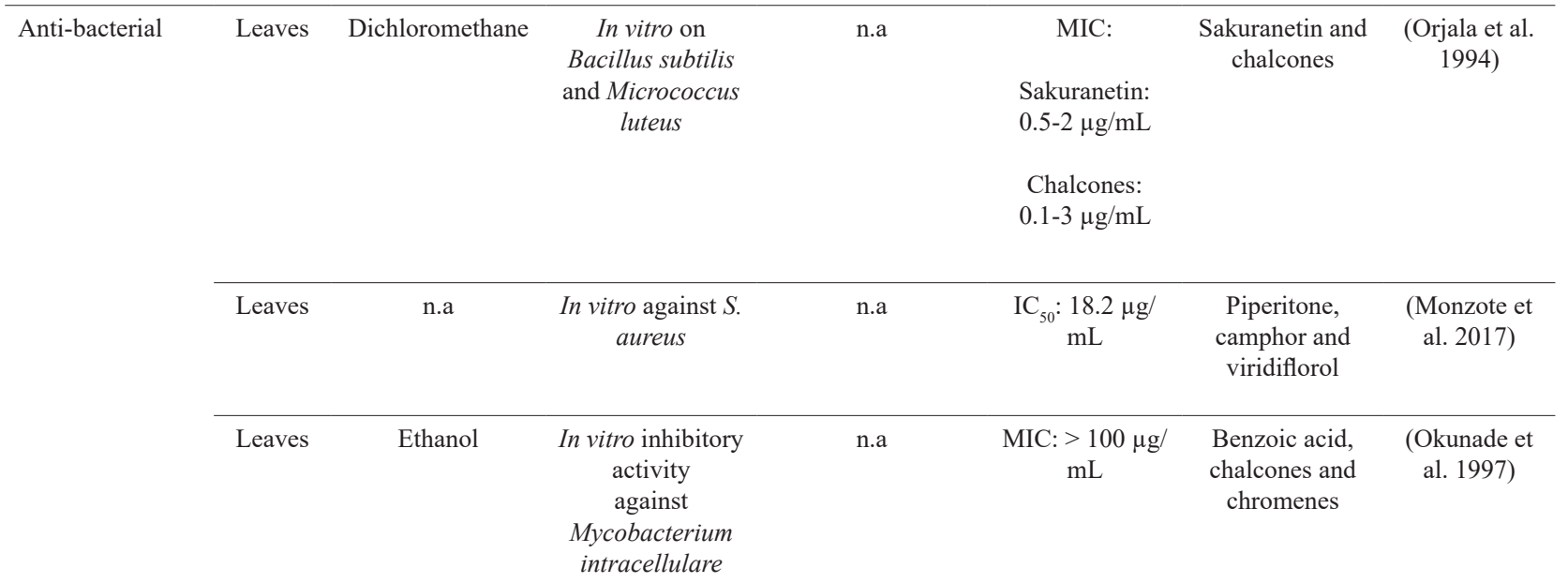




\begin{tabular}{|c|c|c|c|c|c|c|c|}
\hline \multirow[t]{4}{*}{ Insecticidal } & Leaves & n.a & $\begin{array}{l}\text { In vitro on the } \\
\text { larvae and pupae } \\
\text { of } A \text {. aegypti }\end{array}$ & $\begin{array}{l}\text { Mortality of } \\
\text { larvae and normal } \\
\text { abnormalities in } \\
\text { cells of pupae }\end{array}$ & $200-400 \mu \mathrm{g} / \mathrm{mL}$ & Dillapiole & $\begin{array}{l}\text { (Rafael et al. } \\
\text { 2008) }\end{array}$ \\
\hline & Leaves & n.a & $\begin{array}{l}\text { In vitro against } \\
\text { larvae and } \\
\text { adult insects } \\
\text { of Anopheles } \\
\text { marajoara and } \\
\text { Aedesa egypti }\end{array}$ & n.a & $\begin{array}{c}\text { Mortality: } \\
100 \text { ppm } \\
\text { (larvae) } 600 \\
\text { ppm(insects) }\end{array}$ & Dillapiole & $\begin{array}{l}\text { (de Almeida } \\
\text { et al. 2009) }\end{array}$ \\
\hline & Leaves & $\begin{array}{l}\text { Hexane and ethyl } \\
\text { acetate }\end{array}$ & $\begin{array}{l}\text { In vitro on } \\
\text { Antircasia } \\
\text { gemmatalis }\end{array}$ & $\begin{array}{c}\text { Synergistic } \\
\text { action of the } \\
\text { phenylpropanoids, } \\
\text { apiol and } \\
\text { myristicin by } \\
\text { inhibiting the } \\
\text { function of } \\
\text { cytochrome P450 }\end{array}$ & $\begin{array}{c}\mathrm{LC}_{50} \text { : } \\
\text { Hexane extract: } \\
6.35 \mathrm{mg} / \mathrm{mL} \\
\text { Ethyl acetate: } \\
5.79 \mathrm{mg} / \mathrm{mL}\end{array}$ & Apiol & $\begin{array}{c}\text { (Lucena et al. } \\
\text { 2017) }\end{array}$ \\
\hline & Leaves & n.a & $\begin{array}{c}\text { Adulticidal } \\
\text { bioassay } \\
\text { by topical } \\
\text { application on } \\
\text { Musca domestica }\end{array}$ & $\begin{array}{l}\text { Alterations } \\
\text { in a specific } \\
\text { physiological } \\
\text { processes that take } \\
\text { place upon contact } \\
\text { with toxicant }\end{array}$ & $\begin{array}{c}\mathrm{LC}_{50}: \\
6.2-23.8 \mu \mathrm{g} / \mathrm{fly} \\
\\
\mathrm{LC}_{90}: \\
13.3-50.5 \mu \mathrm{g} / \\
\text { fly }\end{array}$ & n.a & $\begin{array}{l}\text { (Mee et al. } \\
\text { 2009) }\end{array}$ \\
\hline
\end{tabular}

\section{ANTI-PARASITIC ACTIVITY AGAINST GENUS Leishmania}

Leishmaniasis is an infectious disease caused by diverse flagellate kinetoplastids of the genus Leishmania (Dal Picolo et al. 2014). The essential oil from the hydrodistillation of fresh $P$. aduncum leaves showed that the high content of sesquiterpenes present possessed antileishmanial activity in an in vitro test on promastigote forms of Leishmania amazonensis, where the $\mathrm{IC}_{50}$ after $24 \mathrm{~h}$ demonstrated a value of $25.9 \mu \mathrm{g} / \mathrm{mL}$, though no explanation for the mechanism of action was proposed (Bernuci et al. 2016). Nerolidol, which is a sesquiterpene compound, has been found to exert antileishmanial activity, where the $\mathrm{IC}_{50}$ after $24 \mathrm{~h}$ in an in vitro test on Leishmania braziliensis demonstrated a value of $74.3 \mu \mathrm{g} /$ $\mathrm{mL}$, whereas the $\mathrm{IC}_{50}$ after $24 \mathrm{~h}$ for $P$. aduncum essential oil was reported to be effective at $77.9 \mu \mathrm{g} / \mathrm{mL}$ (Ceole et al. 2017). Scanning electron microscopy showed severe morphological changes, such as cell shrinkage and alterations in the mitochondria, nuclear chromatin, and flagella pocket on promastigotes, following treatment with nerolidol.

Chalcone derivatives have also been reported to possess antileishmanial activity (Dal Picolo et al. 2014; Torres-santos et al. 1999). Adunchalcone has been obtained from an ethanolic extract of $P$. aduncum leaves, whereas $2^{\prime}, 6^{\prime}$-dihydroxy-4'-methoxychalcone has been obtained from a dichloromethane extract of $P$. aduncum leaves. An in vitro test of adunchalcone on promastigote forms of L. amazonensis and Leishmania shawi obtained an $\mathrm{EC}_{50}$ of 11.03 and $11.26 \mu \mathrm{M}$, respectively, whereas an in vitro test on $2^{\prime}, 6^{\prime}$-dihydroxy-4'-methoxychalcone obtained an $\mathrm{EC}_{50}$ of $0.5 \mu \mathrm{g} / \mathrm{mL}$ against promastigotes and $24 \mu \mathrm{g} / \mathrm{mL}$ against amastigotes of $L$. amazonensis. It has been suggested that the presence of two aromatic rings linked by three carbons containing carbonyl group with a hydrophilic and lipophilic substituent forms the structure of adunchalcone, which inhibits the growth of parasites (Dal Picolo et al. 2014). The mechanism of action for the cytotoxicity of 2',6'-dihydroxy-4'-methoxychalcone has been suggested as being due to the enlargement and disorganisation of mitochondria in L. amazonensis promastigote (Torres-santos et al. 1999). Flores et al. (2009) found that benzoic acid derivatives from ethanol and water extracts of $P$. aduncum leaves also possessed antileishmanial activity and reported that the $\mathrm{IC}_{50}$ against L. braziliensis was $6.5 \mu \mathrm{g} / \mathrm{mL}$ in vitro. P. aduncum extracts from the Atlanta forest have been reported to contain 4-hydroxybenzoic acid, dihydrochalcones and chromenes that contribute to the plant antileishmanial effects (de Almeida et al. 2009). However, none of these studies discussed the potential mechanism of action for this antileishmanial activity.

\section{ANTI-PARASITIC ACTIVITY AGAINST Plasmodium falciparum}

Pink et al. (2005) reported that the essential oil from $P$. aduncum has antiprotozoal activity against $P$. falciparum, 
which is the causal agent of malaria. The essential oil from $P$. aduncum collected in Cuba showed high antiprotozoal activity, where the $\mathrm{IC}_{50}$ value was reported as $1.3 \mu \mathrm{g}$ / $\mathrm{mL}$. The antiprotozoal activity may be attributable to the components piperitone, camphor and viridiflorol found in P. aduncum essential oil. It has been suggested that the mechanism of action for the cytotoxicity could be the decrease in mitochondrial membrane potential following treatment (Monzote et al. 2017; Villamizar et al. 2017).

\section{ANTI-PARASITIC ACTIVITY AGAINST Trypanosoma brucei AND T. cruzi}

The parasitic protozoa for trypanosomiasis ("morning sickness') have been identified as T. brucei and T. cruzi. The antiprotozoal activity of the essential oil from $P$. aduncum leaves showed high activity against $T$. brucei and $T$. cruzi, where the $\mathrm{IC}_{50}$ gave values of 2.0 and $2.1 \mu \mathrm{g} /$ $\mathrm{mL}$, respectively (Monzote et al. 2017). The antiprotozoal activity may be attributable to the presence of piperitone, camphor, and viridiflorol. It has been suggested that the mechanism of action for the antiprotozoal activity could be the reduction in mitochondrial membrane potential of the parasite after treatment (Villamizar et al. 2017).

\section{ANTI-PARASITIC ACTIVITY AGAINST Rhipicephalus (boophilus) microplus}

Silva et al. (2009) reported that a hexane the extraction of $P$. aduncum leaves possessed anti-parasitic activity and reported an $\mathrm{LC}_{50}$ of $9.3 \mathrm{mg} / \mathrm{mL}$ test against $R$. microplus larvae and adult females in vitro. GC-MS analysis indicated that the main compound responsible for the antiparasitic activity was dillapiole. The cytotoxic effect was shown to be caused by alterations in development and physiological disturbances in the metabolism of the parasite (Silva et al. 2009).

\section{ANTI-PARASITIC ACTIVITY AGAINST Schistosoma mansoni}

de Castro et al. (2015) showed that dichloromethane extracts of $P$. aduncum at concentrations of 25,50 , and $100 \mu \mathrm{M}$ caused $100 \%$ mortality in $S$. mansoni adult worms in vitro. GC-MS analysis showed that chalcone was the major compound responsible for the anti-parasitic activity. Treatment with cardamonin caused mortality, and tegumental altered and reduced the oviposition and motor activity of $S$. mansoni worms by inhibiting ATP diphosphohydrolase (de Castro et al. 2015).

\section{ANTIMICROBIAL PROPERTIES ANTIFUNGAL}

Research conducted by Lago et al. (2004) showed that an ethanolic extract of $P$. aduncum leaves possesses fungicidal activity against Cladosporium sphaerospermum and Cladosporium cladosporioides, where the MIC values have been reported to be between 0.5 and $5.0 \mu \mathrm{g} / \mathrm{mL}$. Nerolidol obtained from the essential oil of the fruits of
$P$. aduncum has also demonstrated antifungal properties with an MIC value of $10 \mu \mathrm{g} / \mathrm{mL}$ against $C$. cladosporioides and C. sphaerospermum (Navickiene et al. 2006).

A hydro-distillation of the aerial parts of $P$. aduncum showed that dillapiole possesses antifungal activity, where MIC values in an in vitro test against Clinipellis perniciosa ('witches-broom') were reported to be between 0.6 and $1.0 \mathrm{ppm}$ (de Almeida et al. 2009). In addition, benzoic acid, chalcone, and chromene from ethanolic extracts of P. aduncum were shown to kill Cryptococcus neoformans and Candida albicans with MIC values of more than $100 \mu \mathrm{g} / \mathrm{mL}$ (Okunade et al. 1997). No mechanism of action for the antifungal properties of these compounds was proposed in these studies.

\section{ANTIBACTERIAL PROPERTIES}

The crude of $P$. aduncum leaves from a dichloromethane extract demonstrated significant antibacterial activity towards Bacillus subtilis and Micrococcus luteus (Orjala et al. 1994). In addition, the in vitro inhibitory activity against Mycobacterium intracellulare has been demonstrated with an MIC value of higher than $100 \mu \mathrm{g} /$ $\mathrm{mL}$ (Okunade et al. 1997). P. aduncum taken from the Ciego de Avila Province, which is rich in camphene and isoborneol constituents, has also been shown to have moderate to poor antimicrobial activity against $E$. coli and S. aureus (Gutiérrez et al. 2016). The mechanism of action for the antibacterial properties was not discussed in these studies.

\section{INSECTICIDAL PROPERTIES INSECTICIDAL ACTIVITY AGAINST MOSQUITOES}

Previous studies have shown that the genus Piper is an important pesticide against the genus Aedes due to the presence of phenylpopanoids, lignoids, and flavonoids. Rafael et al. (2008) reported that dillapiole treatment at concentrations of 200 and $400 \mu \mathrm{g} / \mathrm{mL}$ reduced survival and reproduction in Aedes aegypti. The chromosal damaged and nuclear alterations have been induced by dillapiole treatments in larvae and pupae (Rafael et al. 2008). Dillapiole has also been shown to cause mortality in Anopheles marajoara and A. aegypti, where one study found that 100 and 600 ppm killed larvae and adult insects, respectively (de Almeida et al. 2009). However, no explanation for the mechanism of action was proposed in this study. Oliveira et al. (2013) reported an anti-larvicidal activity of $P$. aduncum essential oil against $A$. aegypti.

Research on the topical application of $P$. aduncum against Musca domestica has found that the essential oil from $P$. aduncum leaves has insecticidal properties against houseflies (Mee et al. 2009). However, this study did not discuss the compounds responsible for the insecticidal properties of the essential oil. The mechanism could be explained as resulting from alterations in a specific physiological process that occurs upon contact 
with the toxicant. The insecticidal activity was tested on male and female houseflies of the same species, which were collected from either Chow Kit or the Institute of Medical Research. Houseflies from Chow Kit showed a lower susceptibility to the insecticidal effect of the P. aduncum extract. Cossolin et al. (2019) reported that the essential oil from $P$. aduncum showed toxicity against the brown stink bug Euschistus heros, which usually attacks soy bean plants. It exerted its effect by changing the insects' tissues and mitochondria population and through glycogen and lipid reduction in the body fat cells (Cossolin et al. 2019).

\section{INSECTICIDAL ACTIVITY AGAINST CATERPILLARS}

Hexane and ethyl acetate crude extracts of $P$. aduncum leaves have been shown to possess insecticidal activity against Antircasia gemmatalis caterpillars (Lucena et al. 2017). GC-MS analysis showed that apiol is the major bioactive compound responsible for the insecticidal properties, as it inhibits the function of cytochrome P450. The $\mathrm{LC}_{50}$ of both hexane and ethyl acetate extracts were reported as 6.35 and $5.79 \mathrm{mg} / \mathrm{mL}$, respectively.

\section{ANTITUMOR AND ANTICANCER PROPERTIES}

Research on the flavonoid constituents of the ethanolic extracts of $P$. aduncum leaves showed that concentrations of 50 to $300 \mathrm{mg} / \mathrm{kg}$ body weight had anticancer properties in DMBA-induced rats in vivo (Arroyo-Acevedo et al. 2015). Dihydrochalcone from the dichloromethane extract of $P$. aduncum leaves was also found to possess anticancer activity, inhibiting human glioma and carcinoma of the nasopharynx, human large cell lung carcinoma and human breast cell carcinoma (Wang et al. 2014). In an in vitro study on the cytotoxic activity of $P$. aduncum against human nasopharynx carcinoma cells, the $\mathrm{IC}_{50}$ was reported as $2.3 \mu \mathrm{g} / \mathrm{mL}$, whereas in vitro cytotoxic activity on glioma and carcinoma of human large cell lung and human breast cell tissues obtained an $\mathrm{IC}_{50}$ of between 23 and $27 \mu \mathrm{g}$. The antioxidant capacity of an ethanolic extract of the leaves of $P$. aduncum was tested using a DPPH radical scavenging assay, and $\mathrm{IC}_{50}$ values of between 82 and $220 \mu \mathrm{g} / \mathrm{mL}$ were obtained (Escudero et al. 2008). The antioxidant properties were said to be attributable to gallic acid, chlorogenic acid, catechin and quercetin, which act as free radical scavengers.

\section{OTHER ACTIVITIES}

The major component of $P$. aduncum essential oil, dillapiole exhibited antiviral against West Nile virus (WNV) is a mosquito-borne flavivirus (Radice et al. 2019) and poliovirus (Lohézic-Le Dévéhat et al. 2002). The ethanolic extracts of $P$. aduncum has a gastroprotective effect in mice and antisecretory effect in rats (Arroyo et al. 2013).

\section{CONCLUSION AND PERSPECTIVES}

$P$. aduncum is used as an alternative medicine in the world. It is the most ethnobotanical uses among Piper species. It is particularly important as a traditional medicine for diarrhoea caused by $E$. coli infection and for inducing wound healing. Studies on the phytochemistry of $P$. aduncum have shown that the plant contains many bioactive constituents, including flavonoids, monoterpenes and sesquiterpenes, chalcones, chromenes, phenylpropanoid, and benzoic acid derivatives. Extracts of $P$. aduncum leaves, stems, and fruits have been found to possess anti-parasitic properties against Leishmania, Plasmodium falciparum, Trypanosoma brucei, T. cruzi, Rhipicephalus microplus and Schistosoma mansoni, in addition to their antifungal, antibacterial, insecticidal, antitumor, and anticancer properties. However, the mechanism of action and specific constituents responsible for the biological properties of $P$. aduncum are yet to be fully explored. Further studies on $P$. aduncum, which shows potential utility in treating and preventing infectious diseases are warranted.

\section{ACKNOWLEDGEMENTS}

The authors are thankful to the International Islamic University Malaysia for funding through grant no P-RIGS18-028-0028. MT and DS designed the study, wrote the lay out and approved the final version of the manuscript. MSA, MBAK, and YS involved in literature search and screened the paper. NFAMN wrote the main text and revised the draft into the paper.

\section{REFERENCES}

Ahmad, F. \& Rahmani, M. 1993. Chemical constituents of Piper aduncum Linn (Piperaceae). Pertanika Journal of Science \& Technology 1(2): 185-188.

Arroyo-Acevedo, J., Chávez-Asmat, R.J., Anampa-Guzmán, A., Donaires, R. \& Ráez-Gonzáles, J. 2015. Protective effect of Piper aduncum capsule on DMBA-induced breast cancer in rats. Breast Cancer: Basic and Clinical Research 9: 41-48.

Arroyo, J., Bonilla, P., Morena-Exebino, L., Ronceros, G., Tomas, G., Huamán, J., Raez, E., Quino, M. \& RodriguezCalzado, J. 2013. Gastroprotective and antisecretory effect of a phytochemical made from matico leaves (Piper aduncum). Revista Peruana de Medicina Experimental y Salud Pública 30(4): 608-615.

Bernuci, K.Z., Iwanaga, C.C., Fernandez-Andrade, C.M., Lorenzetti, F.B., Torres-Santos, E.C. Faiões, V.D.S., Gonçalves, J.E., Do Amaral, W., Deschamps, C., Scodro, R.B.D.L., Cardoso, R.F., Baldin, V.P. \& Cortez, D.A.G. 2016. Evaluation of chemical composition and antileishmanial and antituberculosis activities of essential oils of Piper species. Molecules 21(12): E1698.

Ceole, L.F., Cardoso, M.D.G. \& Soares, M.J. 2017. Nerolidol, the main constituent of Piper aduncum essential oil, has anti-Leishmania braziliensis activity. Parasitology 144(9): 1179-1190.

Cossolin, J.F.S., Pereira, M.J.B., Martínez, L.C., Turchen, L.M., Fiaz, M., Bozdoğan, H. \& Serrão, J.E. 2019. Cytotoxicity of Piper aduncum (Piperaceae) essential oil in brown stink bug Euschistus heros (Heteroptera: Pentatomidae). Ecotoxicology 28(7): 763-770. 
Dal Picolo, C.R., Bezerra, M.P., Gomes, K.S., Passero, L.F.D., Laurenti, M.D., Martins, E.G.A., Sartorelli, P. \& Lago, J.H.G. 2014. Antileishmanial activity evaluation of adunchalcone, a new prenylated dihydrochalcone from Piper aduncum L. Fitoterapia 97: 28-33.

de Almeida, R.R., Souto, R.N., Bastos, C.N., da Silva, M.H. \& Maia, J.G. 2009. Chemical variation in Piper aduncum and biological properties of its dillapiole-rich essential oil. Chemistry \& Biodiversity 6(9): 1427-1434.

de Castro, C.C., Costa, P.S., Laktin, G.T., de Carvalho, P.H., Geraldo, R.B., de Moraes, J., Pinto, P.L., Couri, M.R., Pinto, P.D.F. \& Da Silva Filho, A.A. 2015. Cardamonin, a schistosomicidal chalcone from Piper aduncum L. (Piperaceae) that inhibits Schistosoma mansoni ATP diphosphohydrolase. Phytomedicine 22(10): 921-928.

dos Santos, V.L.P., Franco, C.R.C., Amano, E., Messias-Reason, I.J. \& Budele, J.M. 2015. Anatomical investigations of Piper amalago (Jaborandi-Manso) for the quality control. Revista Brasileira de Farmacognosia 25(2): 85-91.

Duarte, M.C.T., Leme, E.E., Delarmelina, C., Soares, A.A., Figueira, G.M. \& Sartoratto, A. 2007. Activity of essential oils from Brazilian medicinal plants on Escherichia coli. Journal of Ethnopharmacology 111(2): 197-201.

Escudero, M.R., Escudero, D.F.R., Remsberg, C.M., Takemoto, J.K., Davies, N.M. \& Yáñez, J.A. 2008. Identification of polyphenols and anti-oxidant capacity of Piper aduncum L. The Open Bioactive Compounds Journal 1: 18-21.

Flores, N., Jiménez, I.A., Giménez, A., Ruiz, G., Gutiérrez, D., Bourdy, G. \& Bazzocchi, I.L. 2009. Antiparasitic activity of prenylated benzoic acid derivatives from Piper species. Phytochemistry 70 (5): 621-627.

Gutiérrez, Y., Montes, R., Scull, R., Sánchez, A., Cos, P., Monzote, L. \& Setzer, W.N. 2016. Chemodiversity associated with cytotoxicity and antimicrobial activity of Piper aduncum Var. Ossanum. Chemistry \& Biodiversity 13(12): 1715-1719.

Hartemink, A.E. 2010. The invasive shrub Piper aduncum in Papua New Guinea: A review. Journal of Tropical Forest Science 22(2): 202-213.

Lago, J.H.G., Chen, A., Young, M.C.M., Guimarães, E.F., de Oliveira, A. \& Kato, M.J. 2009. Prenylated benzoic acid derivatives from Piper aduncum L. and P. hostmannianum C. DC. (Piperaceae). Phytochemistry Letters 2(3): 96-98.

Lago, J.H.G., Ramos, C.S., Casanova, D.C.C., Morandim, A.D.A., Bergamo, D.C.B., Cavalheiro, A.J., Bolzani, V.D.S., Furlan, M., Guimaraes, E.F., Young, M.C.M. \& Kato, M.J. 2004. Benzoic acid derivatives from Piper species and their fungitoxic activity against Cladosporium cladosporioides and C. sphaerospermum. Journal of Natural Products 67(11): 1783-1788.

Lohézic-Le Dévéhat, F., Bakhtiar, A., Bézivin, C., Amoros, M. \& Boustie, J. 2002. Antiviral and cytotoxic activities of some Indonesian plants. Fitoterapia 73(5): 400-405.

Lucena, D.C., Bertholdo-Vargas, L.R., Silva, W.C., Machado, A.F., Lopes, T.S., Moura, S. \& Barros, N.M. 2017. Biological activity of Piper aduncum extracts on Anticarsia gemmatalis (Hübner) (Lepidoptera: Erebidae) and Spodoptera frugiperda (J.E. Smith) (Lepidoptera: Noctuidae). Anais Da Academia Brasileira de Ciencias 89(3): 1869-1879.

Luyen, B.T.T., Thao, N.P., Widowati, W., Fauziah, N., Maesaroh, M., Herlina, T. \& Kim, Y.H. 2017. Chemical constituents of
Piper aduncum and their inhibitory effects on soluble epoxide hydrolase and tyrosinase. Medicinal Chemistry Research 26(1): 220-226.

Mee, C.K., Sulaiman, S. \& Othman, H. 2009. Efficacy of Piper aduncum extract against the adult housefly (Musca domestica). The Journal of Tropical Medicine Parasitology 32(2): 52-57.

Monzote, L., Scull, R., Cos, P. \& Setzer, W. 2017. Essential oil from Piper aduncum: Chemical analysis, antimicrobial assessment, and literature review. Medicines 4(3): 49.

Morandim, A.D.A., Bergamo, D.C.B., Kato, M.J., Cavalheiro, A.J., Bolzani, V.D.S. \& Furlan, M. 2005. Circadian rhythm of anti-fungal prenylated chromene in leaves of Piper aduncum. Phytochemical Analysis 16(4): 282-286.

Moreira, D.D.L., Guimarães, E.F. \& Kaplan, M.A.C. 1998. A chromene from Piper aduncum. Phytochemistry 48(6): 1075-1077.

Navickiene, H.M.D., Morandim, A.D.A., Alécio, A.C., Regasini, L.O., Bergamo, D.C.B., Telascrea, M., Cavalheiro, A.J., Lopes, N.M., Bolzani, V.D.S., Furlan, M., Marques, M.O.M., Young, M.C.M. \& Kato, M.J. 2006. Composition and antifungal activity of essential oils from Piper aduncum, Piper arboreum and Piper tuberculatum. Quimica Nova 29(3): 467-470.

Ndjonka, D., Rapado, L.N., Silber, A.M., Liebau, E. \& Wrenger, C. 2013. Natural products as a source for treating neglected parasitic diseases. International Journal of Molecular Sciences 14(2): 3395-3439.

Okunade, A.L., Hufford, C.D., Clark, A.M. \& Lentz, D. 1997. Antimicrobial properties of the constituents of Piper aduncum. Phytotherapy Research: An International Journal Devoted to Medical and Scientific Research on Plants and Plant Products 11(2): 142-144.

Oliveira, G.L., Cardoso, S.K., Júnior, C.R.L., Vieira, T.M., Guimarães, E.F., Figueiredo, L.S., Martins, E.R., Moreira, D.L. \& Kaplan, M.A.C. 2013. Chemical study and larvicidal activity against Aedes aegypti of essential oil of Piper aduncum L. (Piperaceae). Anais Da Academia Brasileira de Ciencias 85(4): 1227-1234.

Orjala, J., Wright, A.D., Behrends, H., Folkers, G., Sticher, O., Rüegger, H. \& Rali, T. 1994. Cytotoxic and antibacterial dihydrochalcones from Piper aduncum. Journal of Natural Products 57(1): 18-26.

Pink, R., Hudson, A., Mouriès, M.A. \& Bendig, M. 2005. Opportunities and challenges in antiparasitic drug discovery. Nature Reviews Drug Discovery 4(9): 727-740.

Radice, M., Pietrantoni, A., Guerrini, A., Tacchini, M., Sacchetti, G., Chiurato, M., Venturi, G. \& Fortuna, C. 2019. Inhibitory effect of Ocotea quixos (Lam.) Kosterm and Piper aduncum L. essential oils from Ecuador on West Nile virus infection. Plant Biosystem - An International Journal Dealing with all Aspects of Plant Biology 153(3): 344-351.

Rafael, M.S., Hereira-Rojas, W.J., Roper, J.J., Nunomura, S.M. \& Tadei, W.P. 2008. Potential control of Aedes aegypti (Diptera: Culicidae) with Piper aduncum L. (Piperaceae) extracts demonstrated by chromosomal biomarkers and toxic effects on interphase nuclei. Genetics and Molecular Research 7(3): 772-781.

Rali, T., Wossa, S.W., Leach, D.N. \& Waterman, P.G. 2007. Volatile chemical constituents of Piper aduncum L. and Piper 
gibbilimbum C. DC (Piperaceae) from Papua New Guinea. Molecules 12: 389-394.

Silva, W.C., de Souza Martins, J.R., de Souza, H.E.M., Heinzen, H., Cesio, M.V., Mato, M., Albrecht, F., de Azevedo, J.L. \& de Barros, N.M. 2009. Toxicity of Piper aduncum L. (Piperales: Piperaceae) from the Amazon forest for the cattle tick Rhipicephalus (Boophilus) microplus (Acari: Ixodidae). Veterinary Parasitology 164(2-4): 267-274.

Thao, N.P., Luyen, B.T.T., Widowati, W., Fauziah, N., Maesaroh, M., Herlina, T., Manzoor, Z., Ali, I., Koh, Y.S. \& Kim, Y.H. 2016. Anti-Inflammatory flavonoid C-glycosides from Piper aduncum leaves. Planta Medica 82(17): 1475-1481.

Torres-santos, E.C., Moreira, D.L., Kaplan, M.A., Meirelles, M.N. \& Rossi-Bergmann, B. 1999. Selective effect of 2',6'-dihydroxy-4-methoxychalcone isolated from Piper aduncum on Leishmania amazonensis. Antimicrobiral Agents and Chemotherapy 43(5): 1234-1241.

Villamizar, L.H., Cardoso, M.D.G., Andrade, J.D., Teixeira, M.L. \& Soares, M.J. 2017. Linalool, a Piper aduncum essential oil component, has selective activity against Trypanosoma cruzi Trypomastigote forms at $4^{\circ} \mathrm{C}$. Memórias do Instituto Oswaldo Cruz 112(2): 131-139.

Wang, Y.H., Morris-Natschke, S.L., Yang, J., Niu, H.M., Long, C.L. \& Lee, K.H. 2014. Anticancer principles from medicinal Piper (Hú Jiāo) plants. Journal of Traditional and Complementary Medicine 4(1): 8-16.
Muhammad Taher, Mohamad Shahreen Amri, Muhammad Badri Abdul Kudos \& Nur Fasya Ajda Md Nor

Department of Pharmaceutical Technology

Faculty of Pharmacy, International Islamic University Malaysia Jalan Sultan Ahmad Shah

25200 Kuantan, Pahang Darul Makmur

Malaysia

Deny Susanti*

Department of Chemistry

Faculty of Science, International Islamic University Malaysia Jalan Sultan Ahmad Shah

25200 Kuantan, Pahang Darul Makmur

Malaysia

Yandi Syukri

Department of Pharmacy

Islamic University of Indonesia

Yogyakarta, 55584

Indonesia

*Corresponding author; email: deny@iium.edu.my

Received: 6 March 2019

Accepted: 25 March 2020 